\title{
地域リハビリテーションの動向とリハビリテーション医学の課題
}

\section{3. 盛岡北部地域リハビリテーション広域支援センターの経験から} みちのく愛隣協会東八幡平病院 及川 忠人

岩手県リハビリテーション協議会が設置され, 同協議会が岩手県地域リハ支援センターを 指定し，その地域リハセンター（いわてリハセンター）が作成した連携指針により岩手県内 の二箇所の二次医療圈に地域リハビリテーション広域支援センターが設置された。翌年平成 13 年 10 月に我が病院が盛岡北部地域リハビリテーション広域支援センターとして指定を受 けた．当院では盛岡医療圏における連携指針策定等への協力を行い，さらに多くに活動が必 要であったが，指定を受けた初年度には活動期間が半年しか残されておらず，実質的にはリ ハビリテーション連絡協議会の立ち上げと啓発活動を目的とした研修会の開催への対応のみ で余裕がなく初年度は終わり新しい年度になった。これらの反省から新年度への活動の方向 を策定する目的で地域の関連施設に対してアンケート調査を実施した。このアンケートでリ ハスタッフ等の専門職派遣と地域リハビリテーションの考え方や在宅支援等の研修会開催が ニードとして高く, さらに急性期・回復期・維持期リハビリテーションの流れとその中での 患者の情報集約が必要であり，それらを可能とする地域ネットワーク造りが必要であること が分かった。これらの結果に基づいて平成 14 年度の活動計画を策定し，関連町村へのスタッ フ派遣，地域リハビリテーションの考え方や，個別の機能訓練，摂食嶼下訓練等の諸施設へ の技術支援等を活動として位置づけ実施した。しかしながらその実体実状は未だ不十分であ る.

平成 15 年 2 月には全県下の地域リハ広域支援センターの連絡協議会が開催され，地域リハ ビリテーション広域支援センターの未設置の医療圈は全県下の 9 医療圈のうち 2 医療圈を残 すのみとなり, 岩手県の医療圏各圏域での地域リハ広域支援センターの活動が次第に具体化 しつつあるように思われます。

今後, これまでの活動内容を反省し, 広域支援センターの事業展開による地域リハビリテ ーション活動の具体的活動や啓発活動を如何に勧めるか, さらにまた広域支援センターが事 務的役割を果たしながら圈域内の各地方自治体の実務的組織造りに如何に協力支援するか等 が大きな課題となるであろう.

地域リハビリテーション広域支援センターの具体的目標, 活動効果およびそれら評価は, 地域リハビリテーション広域支援センターへの第三者評価の視点を合わせ持ちながら「地域 リハビリテーション活動」を如何に定着させ地域に根ざすかを問い直す方向性が重要であろ う. 